\title{
Ukrainian geomagnetic repeat station network and results of the field work reduced to the epoch 2005.5
}

\author{
Valentyn Maksymchuk ${ }^{1,{ }^{\star}}$, Myxailo Orlyuk ${ }^{2}$, Viktor Tregybenko ${ }^{3}$, \\ Yurij Horodyskyy ${ }^{1}$, Dmytro Marchenko ${ }^{1}$ \\ ${ }^{1}$ Institute of Geophysics NAS of Ukraine, Carpathian Branch, Lviv, Ukraine \\ ${ }^{2}$ Institute of Geophysics NAS of Ukraine, Kyiv, Ukraine \\ ${ }^{3}$ Ukrainian State Geological Prospecting Institute (UkrDGRI), Kyiv, Ukraine
}

\author{
Article history \\ Received September 30, 2011; accepted July 31, 2012. \\ Subject classification: \\ Earth's magnetic field, Repeat station, Secular variation, Magnetic declination.
}

\begin{abstract}
The results of geomagnetic field components of the renewed Ukrainian repeat stations (RS) network are presented. The methods of absolute geomagnetic and astro-geodetic measurements are described. The reduction of geomagnetic field components is carried out to the 2005.5 epoch and a catalogue of RS is created. Maps of magnetic declination for the Ukraine are constructed and compared with results calculated by the IGRF-2005 model.
\end{abstract}

\section{Introduction}

Investigation of the temporal and spatial structure of the Earth's magnetic field (EMF) is important to solve some fundamental problems in geophysics. One problem is the separation of the Earth magnetic field into contribution from sources of internal and external origin, and the separation of the internal sources into the main (normal) field, arising from the dynamo process in the liquid Earth core and a lithospheric field. To solve this problem it is necessary to have precise data of the absolute values of the magnetic field components and their time changes. High quality data of the magnetic field components at the Earth's surface can be obtained from measurements at magnetic observatories (MO) as well as from the periodic measurements (2-5 years) at repeat stations (RS) or from space by satellites. These measurements are extremely important for the following tasks: - estimation and analysis of the time-spatial dynamics of the EMF, its separation into the various parts and investigations of their nature;

- modeling of the Earth magnetic field (for example the IGRF) [Finlay et al. 2010];

- reduction of magnetic surveys and development of maps of the anomalous (lithospheric) magnetic field.

For a temporal reduction of the RS measurements a continuous record of the Earth's magnetic field vector $\mathbf{B}_{\mathbf{X}}, \mathbf{B}_{\mathbf{Y}}$,
$\mathbf{B}_{\mathbf{Z}}, \mathbf{B}_{\mathrm{F}}, \mathbf{B}_{\mathrm{H}}, \mathbf{D}$, I from a MO is needed. Repeated measurements of the Earth magnetism elements at the RS network allow to map the secular variations (SV) of the geomagnetic field. Many organizations from the geology, geophysics, geodesy and military claim for this type of data.

\section{Historical background}

First general magnetic survey in the Ukraine was accomplished during the 1930s and 1940s and the second field campaign in 1969-1972 with a density of 1 point per $400 \mathrm{~km}^{2}$. At the beginning of 1970 a new repeat station network with 39 points was installed in the Ukrainian region [Krutikhovskaya et al. 1973]. Absolute values of the field strength $\mathbf{B}_{\mathbf{F}}$ were measured by the proton magnetometer, $\mathbf{B}_{\mathbf{H}}$ by the quartz $\mathrm{H}$-magnetometer and declination was measured with the fluxgate magnetometer on top of the demagnetized theodolite 3T2K. Mean-square errors of the measurements at this RS network for $\mathbf{B}_{\mathbf{F}}$ component $\pm 2.4 \mathrm{nT}, \mathbf{B}_{\mathbf{H}} \pm 4.0 \mathrm{nT}, \mathbf{B}_{\mathbf{Z}} \pm 2.5 \mathrm{nT}$, D 1.3 minutes of arc. The next magnetic survey at the RS network was done during 1974 and 1975. The components of the geomagnetic field were reduced to 1974.5 by using the data of the magnetic observatories data "Lviv", "Kiev" and "Odessa". This work was used for the mapping of all components of the geomagnetic field for the territory of the Ukraine and the USSR and for the mapping of the main field for the epoch 1975 year [Krutikhovskaya et al. 1982]. Some of these repeat stations were repeated until the year 1985.

After 30 years from the last magnetic survey many points of this network were lost. For this reason, the goal of this work is to analyze the condition, reviving and increasing the existing RS network in Ukraine. In the year 2003 the Carpathian Branch of the Subbotine Institute of Geophysics NAS of Ukraine (CBiGF) and Subbotine Institute of Geophysics NAS of Ukraine (IGF) started this work. 


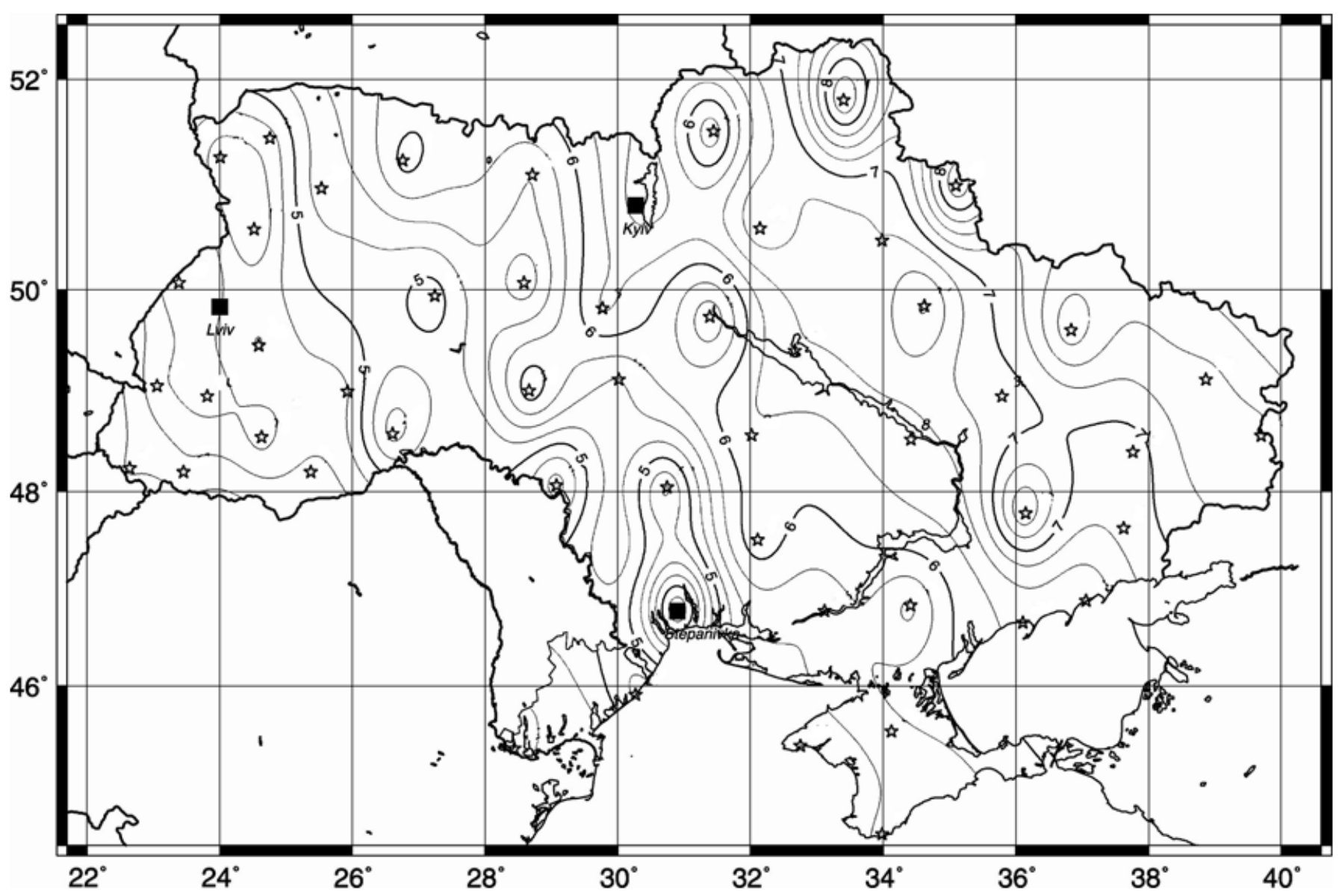

Figure 1. Ukrainian RS Network and magnetic declination D (isogonic counter lines in degree) for the epoch 2005.5. Black stars: RS network; black squares: magnetic observatories.

\section{Ukrainian RS Network}

The RS network in Ukraine was renewed and increased during the years 2005-2006. Most of the new points were reinstalled at the locations of the destroyed points. But reinstallation can't give us the same positions of the points as in 1972 to 1973 . For this reason measured data at the new Ukrainian RS network during 2006 and 2007 cannot be used for the determination of the secular variations since 1974 . This new RS network consists of 52 first order points with a distance between the points of approximately $100-150 \mathrm{~km}$. The density of the RS network is one point per $10,000 \mathrm{~km}^{2}$ with the even distribution in the Ukrainian area. For the astronomical gauge azimuth determination, or in general for the bringing of the theodolite horizontal scale to the geographic meridian several methods, we use the classical method of the horary angle of the celestial body [Pandul 1983]. As it was mentioned for the determination of all components of the Earth magnetic field, it is necessary to determined three independent components. Flux-gate magnetometers LEMI-203 [see the website of the Lviv Center of Institute for Space Research: http: / /www.isr.lviv.ua/products.htm\#Flux-gate magnetometers], installed on top of demagnetized theodolite $3 \mathrm{~T} 2 \mathrm{~K}$, can be used for the determination of the angles $\mathrm{D}$ and I. Module of the complete vector $\mathbf{B}_{\mathrm{F}}$ of the magnetic field was measured by the proton magnetometers MINIMAG and MB-01 (proton magnetometers with achieved accuracy 0.01 and $0.1 \mathrm{nT}$, developed by "Geologorazvedka", St. Petersburg, Russia). In general all recommendations of IAGA was take into account [Newitt et al. 1996]

\section{Results}

The results of the second cycle measurements at Ukrainian RS network were reduced to the epoch 2005.5 [Maksymchuk et al. 2010]. The reduction [Newitt et al. 1996] was based on the data from the magnetic observatories "Kyiv", "Belsk" and "Lviv". In Table 1 all reduced components are shown. In general, comparison of measured values with the modeled ones show us that differences between the linear components $\left(\mathbf{B}_{\mathbf{X}}, \mathbf{B}_{\mathbf{Y}}, \mathbf{B}_{\mathbf{Z}}\right)$ can reach several hundred nT. Differences in the magnetic declination angles at various regions vary from one minute to half degree. If the analytical model field is very flat without any local (regional) gradients (Figure 1), whereas the real measured field composed of big gradient in various area of Ukrainian region. Especially this is visible at the $\mathbf{D}$ component. Magnetic declination $\mathbf{D}$ in the Ukrainian region fluctuates from $4^{\circ}$ at the West to $8^{\circ}$ at the East with the sufficiently complicated spatial structure (Figure 2). Strong regional anomalies can be divided to the three parts: western part of Ukraine, in the region of the MO "Lviv"; southern part of Ukraine near the 


\begin{tabular}{|c|c|c|c|c|c|c|c|}
\hline Nr. & RS Name & $\varphi, \mathrm{N}^{\mathrm{o}}$ & $\lambda, \mathrm{E}^{\mathrm{o}}$ & $\mathbf{B}_{\mathbf{X}}(\mathrm{nT})$ & $\mathbf{B}_{\mathbf{Y}}(\mathrm{nT})$ & $\mathbf{B}_{\mathbf{Z}}(\mathrm{nT})$ & $\mathbf{D}^{\mathbf{o}}$ \\
\hline 1 & Balaklia & 49.603 & 36.500 & 20465 & 2839 & 46377 & 7.884 \\
\hline 2 & Bashtanka & 47.510 & 32.107 & 20977 & 2257 & 44673 & 6.128 \\
\hline 3 & Berduchiv & 50.066 & 28.590 & 19788 & 1769 & 45647 & 5.105 \\
\hline 4 & Beregove & 48.234 & 22.648 & 20587 & 1542 & 44223 & 4.280 \\
\hline 5 & Beregomet & 48.197 & 25.378 & 20700 & 1610 & 44515 & 4.440 \\
\hline 6 & Bila Cerkva & 49.819 & 29.774 & 19829 & 2179 & 45613 & 6.265 \\
\hline 7 & Borynja & 49.055 & 23.059 & 20337 & 1665 & 44540 & 4.677 \\
\hline 8 & Verhnjodniprovsk & 48.523 & 34.421 & 20390 & 2275 & 45550 & 6.362 \\
\hline 9 & Volnovakha & 47.627 & 37.622 & 20617 & 2473 & 46000 & 6.829 \\
\hline 10 & Gadjach & 50.476 & 33.985 & 19249 & 2275 & 46455 & 6.740 \\
\hline 11 & Goluba Zatoka & 44.422 & 33.982 & 22691 & 2223 & 42993 & 5.572 \\
\hline 12 & Horokhiv & 50.580 & 24.522 & 19513 & 1453 & 45747 & 4.259 \\
\hline 13 & Guljaipole & 47.778 & 36.146 & 20775 & 2809 & 45581 & 7.688 \\
\hline 14 & Deljatyn & 48.549 & 24.634 & 20566 & 1738 & 44598 & 4.827 \\
\hline 15 & Dzergynsk & 48.399 & 37.764 & 20512 & 2479 & 45549 & 6.883 \\
\hline 16 & Dymer & 50.806 & 30.274 & 19242 & 2103 & 46308 & 6.236 \\
\hline 17 & Dykanka & 49.840 & 34.625 & 19728 & 2273 & 46134 & 6.571 \\
\hline 18 & Zhashkiv & 49.118 & 30.015 & 19763 & 1900 & 44764 & 5.490 \\
\hline 19 & Zavadiv & 50.064 & 23.390 & 19771 & 1716 & 45381 & 4.959 \\
\hline 20 & Kalna & 48.953 & 23.814 & 20423 & 1738 & 44661 & 4.861 \\
\hline 21 & Kamjanec & 48.578 & 26.696 & 20480 & 1998 & 44848 & 5.568 \\
\hline 22 & Kaniv & 49.739 & 31.386 & 19704 & 1841 & 45433 & 5.336 \\
\hline 23 & Kiverci & 50.971 & 25.533 & 19017 & 1788 & 45904 & 5.374 \\
\hline 24 & Kirovograd & 48.564 & 32.019 & 20233 & 2199 & 45031 & 6.198 \\
\hline 25 & Kovel & 51.449 & 24.758 & 18818 & 1532 & 45811 & 4.658 \\
\hline 26 & Kodyma & 48.064 & 29.075 & 20567 & 1590 & 45109 & 4.412 \\
\hline 27 & Kurortne & 45.904 & 30.268 & 22122 & 2055 & 43851 & 5.280 \\
\hline 28 & Lugansk & 48.559 & 39.696 & 20253 & 2645 & 46353 & 7.431 \\
\hline 29 & Luboml & 51.267 & 24.008 & 18753 & 1430 & 45661 & 4.360 \\
\hline 30 & Nemuriv & 49.008 & 28.667 & 20044 & 2146 & 44674 & 6.106 \\
\hline 31 & Nyzhne Selyshe & 48.198 & 23.456 & 20703 & 1597 & 44083 & 4.407 \\
\hline 32 & Nyzhni Sirogozy & 46.836 & 34.411 & 21333 & 2047 & 44529 & 5.468 \\
\hline 33 & Ovruch & 51.099 & 28.712 & 18931 & 1829 & 45642 & 5.521 \\
\hline 34 & Okunivka & 45.364 & 32.751 & 22110 & 2071 & 43446 & 5.338 \\
\hline 35 & Orelka & 48.956 & 35.794 & 19956 & 2419 & 45901 & 6.905 \\
\hline 36 & Orlovka & 46.661 & 36.106 & 21531 & 2405 & 44877 & 6.355 \\
\hline 37 & Pervomaisk & 48.041 & 30.747 & 20635 & 1623 & 44637 & 4.487 \\
\hline 38 & Pryluki & 50.589 & 32.146 & 19263 & 2330 & 46169 & 6.895 \\
\hline 39 & Reni & 45.338 & 28.441 & 22307 & 1932 & 43032 & 4.925 \\
\hline 40 & Rogatyn & 49.454 & 24.589 & 20111 & 1580 & 45199 & 4.492 \\
\hline 41 & Sarnu & 51.237 & 26.759 & 18959 & 2012 & 46164 & 6.062 \\
\hline 42 & Starobelsk & 49.118 & 38.868 & 20242 & 2638 & 46608 & 7.418 \\
\hline 43 & Stepanivka & 46.777 & 30.900 & 21246 & 1326 & 44222 & 3.554 \\
\hline 44 & Sumy & 51.000 & 35.101 & 19063 & 2814 & 46419 & 8.397 \\
\hline 45 & Urzuf & 46.886 & 37.061 & 21354 & 2374 & 44513 & 6.328 \\
\hline 46 & Kherson & 46.777 & 33.116 & 21344 & 2080 & 44475 & 5.562 \\
\hline 47 & Cherkasy & 49.406 & 32.670 & 19943 & 2261 & 45457 & 6.465 \\
\hline 48 & Chernigiv & 51.512 & 31.443 & 18571 & 1829 & 46767 & 5.628 \\
\hline 49 & Chortkiv & 48.999 & 25.927 & 20424 & 1697 & 45023 & 4.741 \\
\hline 50 & Shepetivka & 49.938 & 27.247 & 20003 & 1709 & 45270 & 4.881 \\
\hline 51 & Shostka & 51.803 & 33.402 & 18676 & 2769 & 46800 & 8.435 \\
\hline 52 & Jastrubivka & 45.516 & 34.127 & 22097 & 2202 & 43647 & 5.688 \\
\hline
\end{tabular}

Table 1. RS catalogue of components of the geomagnetic field for the epoch 2005.5. 


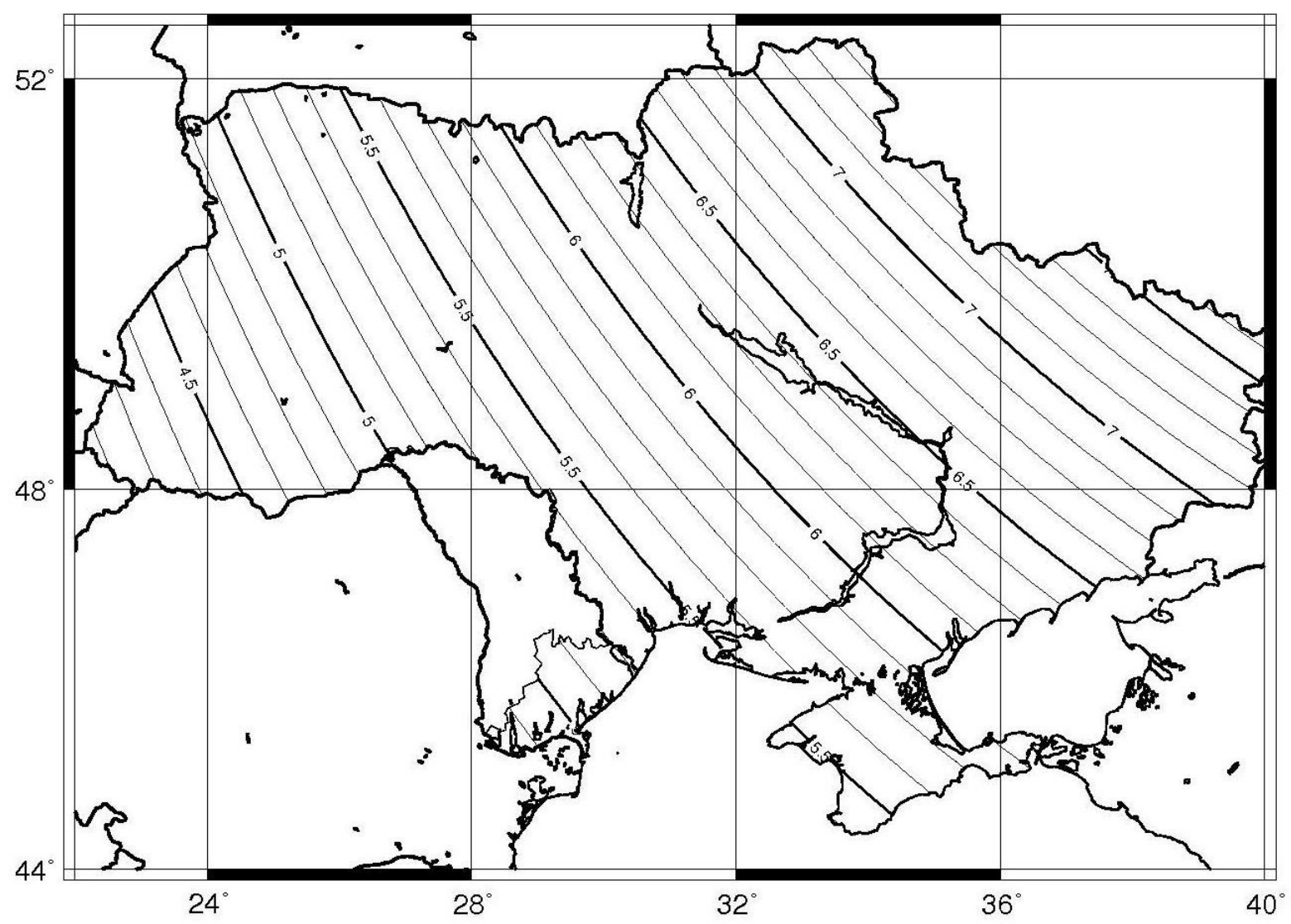

Figure 2. Magnetic declination D (degree) based on IGRF-2005 model.
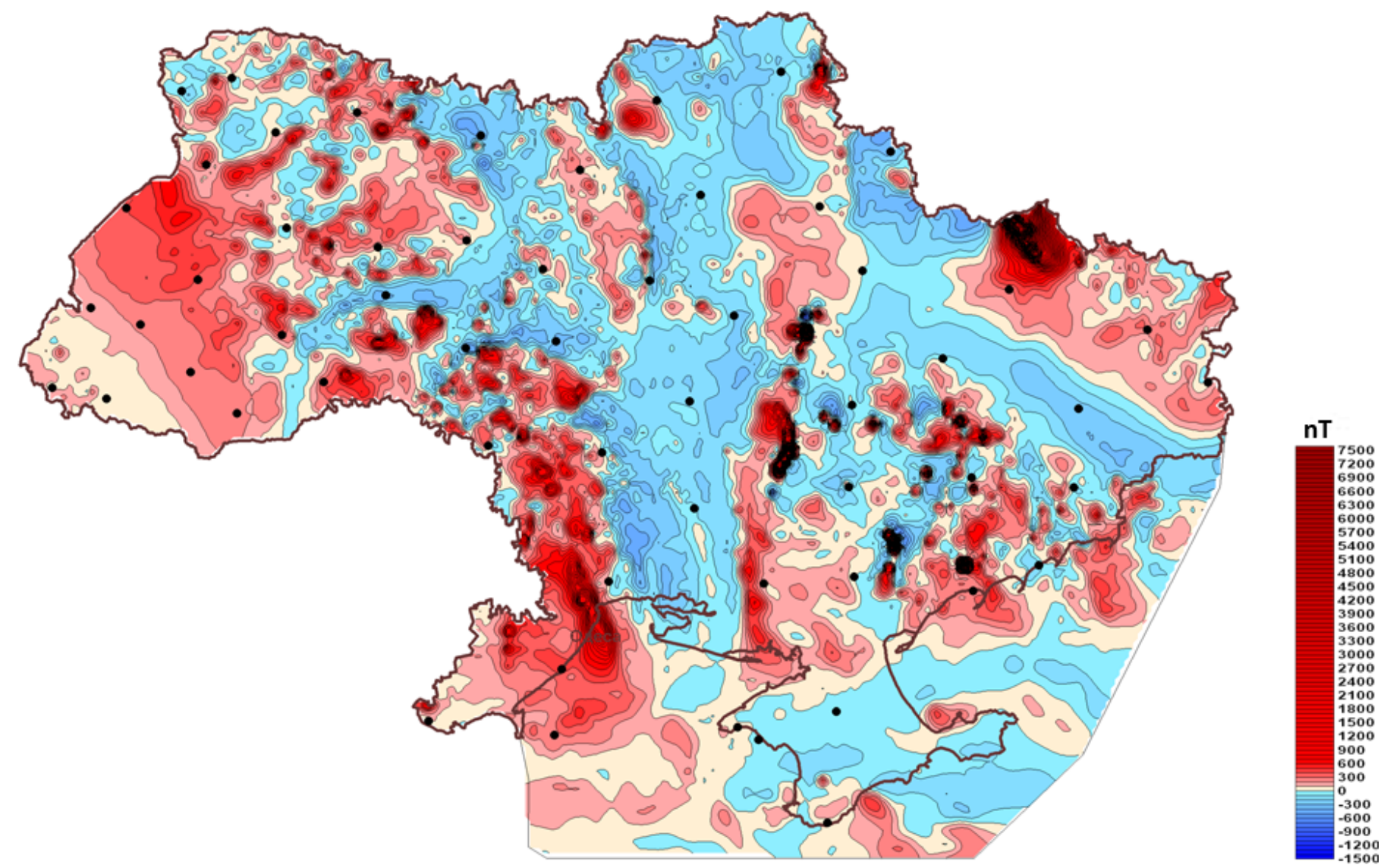

Figure 3. Anomalous magnetic field in Ukrainian area (nT) [Orlyuk and Romenets 2005] 
MO "Odessa" and eastern part near the Ukrainian-Russian border. The structure of the magnetic declination in general agreed with the anomalous magnetic field (Figure 3). Anomalous values of the declination in the western Ukraine coincide with the Lviv regional magnetic anomaly, in the South with the Odessa regional magnetic anomaly, and in the East with the western fork of the Kursk magnetic anomaly. This demonstrates their common nature.

\section{Conclusions}

During 2003 and 2004, 52 repeat stations were renewed and installed at the Ukrainian RS network taking into account the condition of the RS network after 1972. These points are located almost uniformly on the Ukrainian area. Comparison of measured components with modeled ones from IGRF model demonstrates important differences; it is especially the case of magnetic declination $\mathbf{D}$. To estimate with higher accuracy the real field feature and to improve existing maps of the anomalous magnetic field is necessary to densify RS network during next cycle of repeat measurements. Results of geomagnetic measurements will be applied to the adjustment of normal magnetic field model for the Ukrainian territory and for future research of secular variations of the Earth magnetic field.

Acknowledgements. The authors would like to thank the anonymous reviewers and the editor, Dr. Gerald Duma, for their significant comments which led to improvements in the presentation and discussion of these results.

\section{References}

Finlay, C.C., S. Maus, C.D. Beggan, T.N. Bondar, A. Chambodut, T.A. Chernova, A. Chulliat, V.P. Golovkov, B. Hamilton, M. Hamoudi, R. Holme, G. Hulot, W. Kuang, B. Langlais, V. Lesur, F. J. Lowes, H. Lühr, S. Macmillan, M. Mandea, S. McLean, C. Manoj, M. Menvielle, I. Michaelis, N. Olsen, J. Rauberg, M. Rother, T. J. Sabaka, A. Tangborn, L. Tøffner-Clausen, E. Thébault, A.W.P. Thomson, I. Wardinski, Z. Wei and T.I. Zvereva (2010). International Geomagnetic Reference Field: the eleventh generation, Geophysical Journal International, 183, 1216-1230.

Krutikhovskaya, Z.A., I.K. Pashkevich and I.M. Silina (1982). Magnetic model and the structure of the Earth crust of the Ukrainian Shield, Kyiv, Naykova dumka, 216 pp. (in Russian).

Krutixovskaya, Z.A., I.K. Pashkevich, O.M. Rusakov and V.D. Solovjov (1973). Ground absolute magnetic survey of the Ukrainian SSR, Visnyk AN URSR, 9. 101-102 (in Ukrainian). Maksymchuk, V.Yu., M.I. Orlyuk, V.I. Tregybenko, Yu.M. Horodyskyy, V.P. Mjasoedov and E.F. Nakalov (2010). Ground absolute magnetic survey at the Ukrainian RS network for the epoch 2005, Geophysical Journal, Kyiv, 32, (5), 102-166 (in Ukrainian).

Newitt, L.R., C.E. Barton and J.U. Bitterly (1996). Guide for magnetic repeat station surveys, IAGA, Boulder, 112.

Orlyuk, M.I., and A.A. Romenets (2005). New criterion of the Earth's magnetic field disturbance and some aspects of its use, Geophysical Journal, Kyiv, 27, (6), 1012-1023 (in Russian).

Pandul, I.S. (1983). Astro-geodetic determinations on Sun for geographers, geologists and surveyors, Moscow, Nedra, 128.

\footnotetext{
${ }^{\star}$ Corresponding author: Valentyn Maksymchuk, Institute of Geophysics NAS of Ukraine, Carpathian Branch, Lviv, Ukraine; email: vmaksymchuk@cb-igph.lviv.ua.
}

(C) 2012 by the Istituto Nazionale di Geofisica e Vulcanologia. All rights reserved. 